\title{
Effects of fluprazine hydrochloride on an olfactory discrimination in rats
}

\author{
ALLEN E. THORNTON and ERNEST D. KEMBLE \\ University of Minnesota, Morris, Minnesota
}

\begin{abstract}
The effects of $8.0 \mathrm{mg} / \mathrm{kg}$ fluprazine hydrochloride on latencies to locate a buried food reward were examined. The drug had no effect on rats' performance when the reward was placed on the surface of the apparatus, but it produced a marginally significant increase in latency when the reward was buried $4.0 \mathrm{~cm}$ deep. These results provide further evidence that fluprazine interferes in some way with normal olfactory function and that this impairment is not restricted to the processing of conspecific odors. It is suggested that a generalized olfactory impairment may contribute to the drug's effects on copulatory and maternal behavior as well as on conspecific aggression.
\end{abstract}

Fluprazine hydrochloride (DU 27716) and two closely related piperazine compounds (DU 27725 and DU 28412) are known to strongly inhibit offensive attack behavior in rodents (Benton, Brain, Jones, Colebrook, \& Grimm, 1983; Bradford, Olivier, van Dalen, \& Schipper, 1984; Flannelly, Muraoka, D. C. Blanchard, \& R. J. Blanchard, 1985; Olivier, 1981; Olivier, Mos, van der Poel, Krijzer, \& Kruk, 1984; Racine, Flannelly, \& D. C. Blanchard, 1984), while leaving defensive aggression intact (D. C. Blanchard, Takushi, R. J. Blanchard, Flannelly, \& Kemble, 1985; Flannelly et al., 1985; Olivier et al., 1984) or, in some cases, enhancing it (Benton et al., 1983; Olivier, 1981; Racine et al., 1984). This antioffensive effect occurs at dosages well below sedative levels and is not accompanied by major changes in several other social behaviors (Bradford et al., 1984; Olivier, 1981). A number of investigators have noted, however, that the drugs enhance conspecific sniffing and nosing behavior (Olivier, 1981; Olivier et al., 1984; Racine et al., 1984). The latter observations suggest that the antiaggressive effects of these piperazines may be mediated, in part at least, by a disruption in the normal processing of conspecific olfactory stimuli. In a recent experiment, we explored the effects of fluprazine hydrochloride on olfaction, utilizing a two-choice preference apparatus (Kemble, Schultz, \& Thornton, 1986). The drug increased the preference of male rats for conspecific male odors but had no effect on preference for the odors of either estrous females or a food. These results might be interpreted as reflecting a highly selective effect of the drug on the processing of conspecific male odors (presumably at higher CNS levels), an effect that normally precedes conspecific offense, as suggested by Racine et al. (1984). It should be noted, however, that the concentrations of the three odors,

This research was partially supported by an Undergraduate Research Opportunities Program grant to the first author. The authors would like to thank Kevin Flannelly and Dick Lore for their comments on this paper. Please address reprint requests to Ernest Kemble, Division of Social Sciences, University of Minnesota, Morris, MN 52627. though quite salient to human observers, were not known. Thus, it is possible that the drug effect is not restricted to conspecific male odors but reflects a more generalized, perhaps intensity-dependent, effect on olfaction. If so, fluprazine might be expected to disrupt olfactorially guided behavior under other, presumably more demanding, experimental conditions.

This experiment examines the effect of fluprazine hydrochloride on the ability of rats to locate a buried food reward. This task is known to be sensitive to the effects of peripheral anosmia (Alberts \& Galef, 1971). To detect any generalized (e.g., motivational, motor) druginduced changes, latencies to locate an unconcealed reward were also assessed prior to the olfactory test.

\section{METHOD}

\section{Subjects}

The subjects were 18 experimentally naive Holtzman female albino rats weighing 193-266 g. The rats were individually housed in stainless steel cages throughout the experiment.

\section{Apparatus}

Testing was conducted in a $113 \times 113 \times 46 \mathrm{~cm}$ open field constructed of $1 / 4$-in. plywood, painted flat black. The floor of the field was covered with $6 \mathrm{~cm}$ of fir shavings and divided into $22 \times 22 \mathrm{~cm}$ segments by white lines that continued up the inside of each wall to permit localization of each segment beneath the shavings.

\footnotetext{
Procedure

All animals were habituated to the apparatus for $10 \mathrm{~min}$ on 2 consecutive days. At the conclusion of habituation, the rats were food deprived, and training was initiated $23 \mathrm{~h}$ later. The 23-h deprivation schedule was continued throughout the experiment. Amount of food (Purina Lab Chow) was adjusted to maintain the rats at $75 \%-85 \%$ of ad-lib weights. The rats received one trial per day throughout the experiment.

During the first 19 trials, the rats were trained to locate a $2.5-\mathrm{g}( \pm 0.5 \mathrm{~g})$ piece of chocolate-flavored cookie (Nabisco Oreo Cookies), which was placed on the surface of the fir chips in the center of one of the $25 \mathrm{seg}$ ments. Cookie placement was randomly varied on each trial. On each trial, the rat was gently placed in one corner of the apparatus and given up to $5 \mathrm{~min}$ to locate and grasp the cookie. Latencies were recorded by stopwatch. Any uneaten reward was placed in the home cage with the rat at the end of each trial. By Trial 19, rats achieved a high level
} 
of accuracy in locating the reward $(100 \%$ success rate for all rats on Trials 15-19).

On Trial 20, the effects of fluprazine hydrochloride on reward finding at the surface were assessed. Latency-balanced groups of 9 rats received intraperitoneal injections of $8.0-\mathrm{mg} / \mathrm{kg}$ fluprazine hydrochloride (drug group) or an equivalent volume of isotonic saline (saline group) $30 \mathrm{~min}$ prior to testing. The $8.0-\mathrm{mg} / \mathrm{kg}$ dose produces striking antiaggressive effects and is well below sedative levels $(45-60 \mathrm{mg} / \mathrm{kg})$ of this drug. At the conclusion of this test, rats were allowed to recover from drug effects for $72 \mathrm{~h}$ before training was resumed.

On Trials 21-31, the rats were trained to locate the reward when it was buried beneath the fir shavings. The depth of the reward was gradually increased to $4.0 \mathrm{~cm}$ (Trials 21-26), and training continued for 5 additional trials. At the end of this training period, rats located the buried reward with high accuracy $(97 \%$ success rate for all rats during the last 5 trials).

Drug effects on buried reward retrieval were assessed on Trial 32. Thirty minutes prior to this test, the rats $(N=9)$ that had previously received saline injections were treated with $8.0 \mathrm{mg} / \mathrm{kg}$ fluprazine, and the rats $(N=9)$ that had previously received fluprazine were injected with saline.

\section{RESULTS}

The results of this experiment are summarized in Figure 1, which depicts mean latencies in drug- and saline-treated groups to find and grasp the food reward when it was placed on the surface (left) and when it was buried $4 \mathrm{~cm}$ deep (right). As expected, latency balancing of the groups resulted in highly similar latencies prior to the first (surface) test (saline, mean $=26.0 \mathrm{sec}$; drug, mean $=19.9 \mathrm{sec}, t<1.0$ ) As can be seen in Figure 1, the latencies of the groups were also quite similar following saline or drug treatment with no suggestion of a drug effect $(t<1.0)$. Prior to the second (buried) test group,

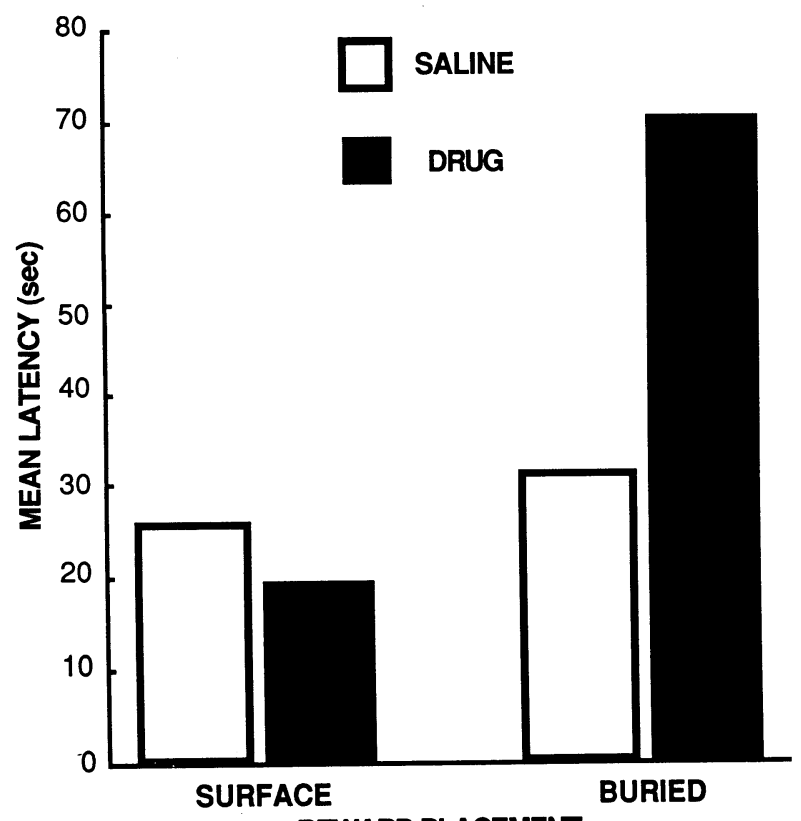

REWARD PLACEMENT

Figure 1. Mean latency to grasp a food reward placed on the shavings surface (Surface) and buried to a depth of $4.0 \mathrm{~cm}$ (Buried) by rats $30 \mathrm{~min}$ after injection with isotonic saline (Saline) or $8.0 \mathrm{mg} / \mathrm{kg}$ fluprazine hydrochloride (Drug). latencies were again similar (saline, mean $=53.7 \mathrm{sec}$; drug, mean $=38.3 \mathrm{sec}, t<1.0$ ). The somewhat higher mean of the saline group is due entirely to the aberrant performance of 1 rat. As can be seen in Figure 1 (right), treatment with fluprazine was followed by a marginally significant increase in latency $[t(17)=1.88$, $.05<p<.10]$, relative to latency of saline-treated rats.

\section{DISCUSSION}

The disruptive effect of fluprazine hydrochloride on the location of a buried, but not unconcealed, food reward provides further evidence that the drug interferes with normal olfactory function. Although the effect was marginally significant, it should be noted that both normal and drug-treated rats found the buried reward with reasonably short latencies. This suggests that the task was not particularly demanding and that a more difficult discrimination would yield clearer effects. Of particular interest, these data also provide evidence that the olfactory effects of fluprazine are not restricted to the processing of conspecific male odors by males, as earlier observations suggested (Kemble et al., 1986; Racine et al., 1984). Although it is certainly possible that fluprazine has a particularly potent effect on male conspecific odor processing, a more generalized olfactory effect might help to explain its effectiveness in disrupting male copulatory behavior (Flannelly, Lim, Diamond, D. C. Blanchard, \& R. J. Blanchard, 1985) and maternal behavior (Kemble \& Schultz, 1986), as well as offensive aggression. The importance of olfaction in all three behaviors is well documented (e.g., Benuck \& Rowe, 1975; Flannelly \& R. J. Blanchard, 1982; Thor \& Flannelly, 1977).

\section{REFERENCES}

Alberts, J. R., \& GAlEF, B. G. (1971). Acute anosmia in the rat: A behavioral test of a peripherally-induced olfactory deficit. Physiology \& Behavior, 6, 619-621.

Benton, D., Brain, P., Jones, S., Colebrook, E., \& Grimm, V. (1983). Behavioural examinations of the anti-aggressive drug fluprazine. Behavioural Brain Research, 10, 325-338.

BENUCK, I., \& RowE, F. A. (1975). Centrally and peripherally induced anosmia: Influences on maternal behavior in lactating female rats. Physiology \& Behavior, 14, 439-447

Blanchard, D. C., Takushi, R., Blanchard, R. J., Flannelly, K. J., \& Kemble, E. D. (1985). Fluprazine hydrochloride does not decrease defensive behaviors of wild and septal syndrome rats. Physiology \& Behavior, 35, 349-353.

BradFord, L. D., Olivier, B., van DALEN, D., \& SCHIPPER, J. (1984). Serenics: The pharmacology of fluprazine and DU 28412. In K. A. Miczek, M. R. Kruk, \& B. Olivier (Eds.), Ethnopharmacological aggression research (pp. 191-207). New York: Liss.

FlanNelly, K. J., \& BlanchaRd, R. J. (1982). Decreased aggressive and social responsiveness of chronically anosmic male rats. Bulletin of the Psychonomic Society, 19, 173-176.

Flannelly, K. J., Lim, H., Diamond, M., Blanchard, D. C., \& BLANCHARD, R. J. (1985). Fluprazine hydrochloride decreases copulation in male rats. Pharmacology Biochemistry \& Behavior, 22, 1-4.

Flannelly, K. J., Muraoka, M. Y., Blanchard, D. C., \& BlaNCHARD, R. J. (1985). Specific anti-aggressive effects of fluprazine hydrochloride. Psychopharmacology, 87, 86-89.

Kemble, E. D., \& SCHULTZ, L. A. (1986). Effects of fluprazine hydrochloride on maternal behavior in mice. Unpublished manuscript.

Kemble, E. D., Schultz, L. A., \& Thornton, A. E. (1986). Effects of fluprazine hydrochloride on conspecific odor preferences in rats. Physiology \& Behavior, 37, 53-56.

OLIVIER, B. (1981). Selective anti-aggressive properties of DU 27725 : Ethological analyses of intermale and territorial aggression in the male rat. Pharmacology, Biochemistry \& Behavior, 14(Suppl. 1), 61-77.

Olivier, B., Mos, J., van der Poel, A. M., Krijzer, F. N. C., \& KRUK, M. R. (1984). Effects of a new psychoactive drug (DU 27716) on different models of rat agonistic behavior and EEG. In K. J. Flan- 
nelly, R. J. Blanchard, \& D. C. Blanchard (Eds.), Biological perspectives on aggression (pp. 261-279). New York: Liss.

RaCine, M. A., FlanNelly, K. J., \& BlanchaRD, D. C. (1984). Antiaggressive effects of DU 27716 on attack and defensive behaviors in male mice. In K. J. Flannelly, R. J. Blanchard, \& D. C. Blanchard (Eds.), Biological perspectives on aggression (pp. 281-294). New York: Liss.
ThoR, D. H., \& FlanNelly, K. J. (1977). Social-olfactory experience and initiation of copulation in the virgin male rat. Physiology \& Behavior, 19, 411-417.

(Manuscript received for publication May 22, 1986.) 